\title{
The Politics of Impunity and the Shifting Media Landscape in Kenya
}

\author{
By Philip Onguny*
}

\begin{abstract}
This article focuses on state-media relations and the shifts in the overall media landscape in Kenya. Drawing on a political economy approach to media operations in Kenya, it argues that while there are competing meanings over what constitutes "news values", "editorial independence", and "critical media", changes in political regimes and unclear media regulations contribute to political and/or corporate interference on media coverage of corruption and political impunity. This renders media operations problematic at the normative and operational levels. The discussion situates these arguments within the contexts of "policy laundering" and "critical junctures", seeking to establish whether the shifting media landscape is a function of increased information and communication affordability or, instead, an indication that critical media are on the decline. Overall, the article provides an assessment of key temporal periods that have shaped media regulatory frameworks to show how political and/or corporate interests have influenced journalistic practices and editorial independence over time and space.
\end{abstract}

Keywords: Kenyan media, media regulations, editorial independence, political impunity, policy laundering, safety of journalists, critical junctures

\section{Introduction}

Kenya has been perceived as one of the few African countries with a "pluralist" media, somewhat related to conditions under which media outlets operate. For instance, a recent report by Reporters Without Borders (2018) ranks Kenya $96^{\text {th }}$ (out of 180 countries) on World Press Freedom Index, a 4-point improvement from $2015^{1}$. However, according to the 2019 Corruption Perception Index by Transparency International, Kenya scores 28 out of 100 which highlights the slow progress in fighting corruption ${ }^{2}$. The same report places the average score in Sub-Saharan Africa at 32 and the global average score at 43. While Kenya's new constitution, adopted in 2010 following the 2007/08 post-election violence, recognizes the need for journalists to exercise their profession freely and responsibly, "a hostile and inadequate political, legal, policy and regulatory environment continues to negatively impact the media in Kenya" (Mbeke et al., 2010, p. 7). For instance, media coverage of insecurity, high-level corruption, and the past ICC proceedings against President Uhuru Kenyatta and his deputy William Ruto have been subjected to strict scrutiny by state organs (Mueller, 2014; Ogenga, 2013).

\footnotetext{
*Assistant Professor of Conflict Studies, Saint Paul University, Canada.

${ }^{1}$ For more details on the 2018 World Press Freedom Index, see https://rsf.org/en/ranking/2018. [Accessed on 25 August 2018].

${ }^{2}$ See Transparency International (2019). Corruption Perceptions Index, available online via https:// www.transparency.org/en/cpi/2018/results/ken. [Accessed on 18 July 2020].
} 
While it is true that "there is a relatively free media and general respect for freedom of expression" in Kenya (Kanyinga 2014, p. 11), there are several concerns with regard to political and corporate interference on media content, particularly on corruption and political impunity. At the centre of these concerns is how to protect journalists and their sources in an environment increasingly marked by high intolerance toward critical media. Although there are varying views on what falls within the purview of critical media, Fuchs (2010) reminds us that "an interpretation of media content is critical if the consumed form or content causes subjective insights that allow the recipients to question certain forms of domination, develop ideas of alternative models of existence that advance cooperation and can potentially guide transformative actions and social struggles" (p. 180). Based on this logic, some may attribute the presence/absence of critical media to formal institutionalization of norms and best practices determining journalistic practice (Benson, 2006; Couldry et al., 2010). However, this is not always the case in environments where formal institutionalization of such media practices exists alongside informal institutionalization. In such circumstances, one can certainly expect editorial independence to depend, to a large extent, not on media regulatory frameworks or policies in place, but on written and/or unwritten policies of the state as well as the political environment. This is particularly true in countries with high levels of corruption and political impunity such as Kenya, where several unwritten rules form part of the broader policies that determine media operations. These unwritten rules, often created through social-political bargaining processes, may translate into self-censorship, especially when threats and hefty fines are used as potential means to regulate media content on sensitive topics such as high-profile corruption and national security.

As one would expect, the resilience of journalists and editors in such environments is uncertain. In Kenya, the progressive disappearance of the Jicho $P e v u^{3}$ series, formerly aired on Kenya Television Network (KTN) serves as a good example. The Jicho Pevu series had become a household name, exposing a wide range of social, political, and economic impunities within the country, some of which involved individuals at high levels of the government (Kanyinga, 2014). Some of the topics covered included the alleged rigging of the 2013 elections, exposure of drug hauls involving key politicians and government officials, and the supposed cover-up of government failures during terror attacks at Nairobi's Westgate Mall and Garissa University. Given the prevalence of Jicho Pevu and the appeal it created around "digging up political dirt", some of its investigative journalists (e.g., Mohammed Ali and John Allan Namu) became subjects of constant death threats and harassment. Some describe such practices, where state/corporation interests interfere with media content, as a form of "media capture" or "state capture" (Wasserman, 2020; Schifrin, 2017).

While these observations provide important insights into the role played by state in influencing media operations, journalistic practices have also raised questions with respect to the institutionalization of political impunity. Authors such as Ireri (2016) have highlighted the prevalence of corruption in Kenyan

\footnotetext{
${ }^{3}$ Jicho Pevu is a Swahili word for "critical eye" or "investigative lens".
} 
media, arguing that "cash money (40\%) is the most common form of corruptionand politicians are the top bribe-givers to local journalists, followed by businesspeople" (p. 245). Other studies have also pointed out the problems of media literacy and insufficient training among journalists and how they compromise the overall quality of news media. This is the case of studies conducted by Mbeke et al., (2010) suggesting that, "media organizations (in Kenya) place a low premium on investigative journalism and hardly prioritize it" (p. 8). Further, the "poisonous rhetoric" circulated through new and/or interactive media have increasingly compromised the credibility of several journalists and their parent media outlets. These concerns may explain why the Kenyan government has been keen on enacting restrictive media policies over the years, particularly following election cycles which often turn violent.

For instance, following the aftermath of the 2007-2008 elections, the state proposed policies that allowed for the surveillance of text messages suspected of spreading hate messages. This extended to the use of information and communication technologies (ICTs) (Mitullah et al., 2015). Recently, concerns around the circulation of "fake news" in Kenya have also prompted questions on whether more policies are underway to curb online content (Posetti and Matthews, 2018). While untrue or false stories may have serious implications on public opinion, one emerging problem is that the state appears to capitalize on such circumstances to further infringe on freedoms of expression and on online media content. This means independent newsgathering, including the anonymity of journalists and their sources, can no longer be guaranteed because interested parties increasingly have the means to access the digital footprints. In fact, authors such as Mitullah et al., (2015) have pointed out that, "registration of SIM cards enables the government to trace sources of information and mobile phone signals" (p. 8).

This article focuses on the intersections between media regulations, statemedia relations, and the shifts in the overall media landscape in Kenya. It adopts a political economy approach (PEA) to show how the dynamism around media regulations in Kenya is closely aligned with the shifts in political regimes which, depending on the government in place, establish regulations and specialized state agencies that control media content. PEA is used to establish the linkages "between interests, incentives and institutions", and how they transform the overall media landscape (see Hudson and Marquette, n.d.).

The article argues that the fluidity characterizing Kenya's media regulatory framework not only contributes to the decline in editorial independence and critical news reporting, it also institutionalizes political impunity. The article begins by providing an overview of the media landscape in Kenya before focusing on media concentration and ownership patterns. It then shifts the focus to media regulatory frameworks and how they have informed journalistic practices over time. Finally, it situates these debates within the contexts of policy laundering (Hosein, 2006), journalistic field (Benson, 2006; Couldry et al., 2010) and critical junctures (McChesney, 2007). 


\section{Overview of the Media Landscape in Kenya}

Although the Kenyan media environment is considered to be resilient, dynamic, pluralistic, and somewhat critical ${ }^{4}$, significant changes have taken place in Kenya's overall information ecosystem. Understanding this resilience requires an assessment of three temporal periods, which have marked important shifts in media practice. That is, the 1990-2000, the 2000-2010, and post-2010 media environments. More details about media environments prior to the 1990s are found in the works of Ochilo (1993), Faringer (1991), Moggi and Tessier (2001), Dixon (1997), and Okoth-Owiro (1990).

The 1990-2000 period was mainly characterized by strict state-led media control despite the reforms that saw the restoration of multiparty politics (Obonyo, 2003). For instance, political gatherings and media coverage of government activities in a negative light was almost always unlawful. In fact, until 1982, Kenya was regarded a de facto one-party state, and it was not uncommon for the parliament to establish laws with little to no consultation with media organizations (Widner, 1992). This seemed to be the approach the then ruling party (Kenya Africa National Union - KANU) took in its attempt to influence policies on media and on other issues of public concern (Obonyo, 2003, Widner, 1992). This provided the state-owned media - Kenya Broadcasting Corporation (KBC) - with the leverage as the primary source of information. As a result, the independent and privately-owned media that existed (e.g., Nation Media Group and The Standard Group) were confined to limited airwaves. It is worth noting that even though independent news media were stifled through restrictive media policies, commercial and political interest progressively infiltrated media operations, which provided foundation-level structures for grass-root opposition politics (Haugerud, 1995; Widner, 1992).

It was not until the 2000s (2000-2010) when the government embarked on ambitious political reforms which included a revision of the existing media laws/regulations. These reforms can be attributed to several factors. First, the end of Moi's 24-year authoritarian regime provided room to readjust policies on democratic and civil liberties that had stalled for several years (Shilaho, 2013). With the formation of a new government in 2002 (The National Rainbow Coalition, NARC), many expected to see a series of political and institutional reforms. However, since the anticipated reforms were slow to materialize, many accused the NARC government of rolling back the reforms they had promised the electorate once they ascended to power (Mueller, 2014; Shilaho, 2013). Second, the perceived deception by the NARC government was blamed, in part, for reviving inter-ethnic hatred, and the subsequent sensationalist media coverage of the 2007 election campaigns (Lynch, 2014). This is why recent studies suggest that the 2007-2008 post-election violence provided grounds for the state to amend self-regulatory bodies such as the then Media Council of Kenya (MCK) and Communication Council of Kenya (CCK), all of which were previously tasked with overseeing media practice (Sommerville, 2012). Third, the 2000-2010 period

\footnotetext{
${ }^{4}$ See Reporters Without Borders https://rsf.org/en/kenya. [Accessed 31 August 2018].
} 
marked one of Kenya's worst ethno-political violence, as more than 1000 lives were lost during the 2007-2008 post-election violence (Lynch, 2008). At the core of this violence were concerns about vernacular media's role in fomenting intergroup hatred before, during, and after the elections (Onguny, 2016). More importantly, the incentivization of violence by political elites became very apparent, which encouraged the establishment of a series of regulations aimed at curbing hate speech, political incitement, and inter-ethnic prejudices (Sommerville, 2012; Lynch, 2014). Moreover, with the confirmation of charges against Joshua Sang, one of the vernacular FM radio journalists, the 2000-2010 period raised questions with respect to professional journalism in the country. Nonetheless, the 2000-2010 period also saw a sharp and steady increase in the number of independent news media, particularly vernacular FM radio stations adding to media pluralism and diversity of opinions (Ogolla, 2011; Mbeke et al., 2010).

Finally, the post-2010 media environment has been characterized by a new constitutional dispensation, a notable effort in supporting democratic changes. In a sense, the 2010 constitution was a by-product of the 2007/2008 post-election violence and its aftermath. Although some may argue that its practical application is still a subject of debate, it is undoubtful that the document has attenuated political powers in the form of devolved government. The 2010 constitution also ushered in new media reforms in an attempt to put an end to sensationalist reporting, often driven by identity, personality, and ethnic politics (Shilaho, 2013; Lynch, 2014). Although the new regulations also sought to protect the media, the controlled coverage of the ICC proceedings against president Kenyatta and his deputy demonstrated that each political regime sets its own rules with respect to media operations (Mueller, 2014; Ogenga, 2013). Accordingly, the Jubilee government, which came to power in 2013, has been accused of using unwritten rules to control media discourse particularly on issues relative to political impunity (Shilaho, 2018; Lynch, 2014; Mueller, 2014). For instance, the consolidation of state's advertisements through the newly created Government Advertisement Agency represents one of the indirect ways in which the state ensures "media capture". That is, given the significance of advertisement revenues in media operations, the incumbent regime may have found a way to increase its leverage on media coverage of controversial topics implicating its officials (Media Policy Research Center, 2015; Muhatia, 2017). While it is reasonably true that the initiative may help the government reduce its spending, the agency uses its newlyfound monetary power to influence media content at the editorial level (Muhatia, 2017). As a consequence, news outlets perceived to be critical of the state have seen their ad revenues dwindle due to withdrawal of government advertisements. The post-2010 media landscape has therefore been marked by an increase in both formal and informal institutionalization of media regulatory frameworks.

Together, the three broad periods show how the media landscape in Kenya is relatively linked to changes in political regimes. If these patterns are indicative of anything, then one can certainly expect media regulatory frameworks to remain unstable in the long-term. Similarly, and owing to the steady growth of independent and commercial media, journalists and news editors will remain at a crossroads. They will constantly wrestle with the idea of adopting a more critical 
perspective on matters of political impunity and risk sanctions or taking part in the overall impunity process by accepting "brown envelops" in order to bury or water down certain news stories. Regardless of these choice alternatives, it is undoubtful that political impunity and corruption have risen to worrying levels (Shilaho, 2018; Schmidt and Deselaers, 2015).

\section{Media Reach and Concentration}

In order to understand the links between political impunity and the shifts in Kenya's media regulatory frameworks, it is worth discussing media reach and concentration more broadly. Such an overview is important not only because the distribution between media formats (e.g., radio, TV, newspaper, etc.) is unbalanced, but the impact these regulations have on different media is equally disproportionate. Admittedly, radio still remains the primary means of information despite the increase in the number of Kenyans with access to digital technologies. The annual statistics by the BBC Media Action (2017) show that 96-98\% of Kenyans have access to radio, followed by mobile phones at $95-97 \%$, then TV at $81-89 \%$ and finally Internet at $51-58 \%$.

The completion of the digital migration process in 2015 also brought about new forms of media experiences. According to the International Telecommunication Union - ITU (2017), digital migration saw the population covered by TV grow from $55 \%$ to $66 \%$. The same report shows that the number of broadcasters increased from 14 to 65 , with about 22 broadcasters reaching multiple cities (up from just 5). The growth also indicate that the Kenyan media sector is increasingly becoming expansive and diversified in terms of content, all of which tilt the patterns of media concentration and ownership. To date, seven media houses remain the most dominant. These include Nation Media Group, Standard Media Group, Royal Media Services, Radio Africa, Kenya Broadcasting Corporation, and TV Africa Holdings. One common factor is that the majority, if not all, are controlled by political elites or influential entrepreneurs who, in one way or another, are linked to the current or previous governments. The concentration of media in the hands of few elites is however nothing new. As Ogola (2015) reminds us, "the exponential growth of the media (particularly in the 1990s) saw the emergence of the so-called 'gutter press' - publications that were often funded by politicians to malign their adversaries, ruin reputations or settle scores" (pp. 9596).

Media ownership patterns have therefore remained relatively the same, with elite-centered media oligopolies. For example, the Royal Media Services, owned by businessman Samuel K. Macharia, controls almost all privately-owned ethnic/vernacular radio stations (at least 14 vernacular FM stations), including dominant news outlets such as Citizen radio, Hot 96 FM, Citizen TV, and iNooro $\mathrm{TV}^{5}$. Kenya Broadcasting Corporation, on the other hand, is a state-run media group, which oversees KBC TV, KBC Radio, y254 TV, Coro-FM, Ingo-FM,

\footnotetext{
${ }^{5}$ See https://www.royalmedia.co.ke. [Accessed 28 August 2018].
} 
Mayienga-FM, Pwani-FM, Kitwek-FM, Iftin-FM, among others ${ }^{6}$. The largest (in terms of circulation) and probably the most influential media organization is Nation Media Group. It is also the second oldest media group after the Standard Media Group. Owned by philanthropist The Aga Khan, Nation Media controls Daily Nation newspaper, Nation Television (NTV), Spark TV, the East African, Taifa Leo, Easy FM, K-FM, Dembe-FM, the Monitor (Uganda), among others. The group owns at least eight print newspapers, five broadcast media, and four online/digital media subsidiaries ${ }^{7}$.

The Standard Media Group is the oldest media organization and second largest in terms of concentration. It is controlled by the retired president Moi, his family, and business affiliates. The group owns popular TV stations such as the Kenya Television Network (KTN), Bamba TV, Farmers TV, the Standard newspaper, the Nairobian, Radio Maisha, Vybez Radio, Spice-FM, and Think Outdoor, an advertising company ${ }^{8}$. Other significant media houses include TV Africa holdings, which is under the purview of Kenyatta's family and affiliates. They oversee K24 TV, People Daily, and Kameme FM. Radio Africa Group, coowned by businessman Kiprono Kittony, is also an important media outlet in the country. It controls at least six radio stations (Classic 105, Radio Jambo, Kiss 100, Relax FM, East FM and X FM) a TV station - Kiss TV and a newspaper - The Star Newspaper. Other notable media owners include philanthropist Chris Kirubi who owns Capital FM, one of the most popular urban radio stations in the country.

In short, although media ownership in Kenya displays competitive and dynamic tendencies, a close examination of media concentration and ownership patterns not only shows the extent to which the Kenyan media are in the hands of a handful political elites; it also highlights the fluidity around media regulations, particularly during elections when political and corporate interests largely infiltrate news media. A potential explanation for this is that different media outlets often have a tilt toward specific political candidates and/or parties. Given this, it is undoubtful that commercial and political interests drive the growth, ownership patterns, and media regulatory frameworks in the country.

\section{Media Regulations and the Shifts in Journalistic Practices}

The changing media landscape has also impacted journalistic practices over time and space. Prior to the 2010 constitution, section 79 of the previous constitution remained the primary framework around which media operations were grounded (Moggi and Tessier, 2001; Okoth-Owiro, 1990). This was supplemented by several Acts such as Defamation Act, Public Order Act, Information and Broadcasting Act, The Books and Newspapers Act, Kenya Broadcasting Act, and Official Secrets Act, most of which were unfocused and/or vague (Ogbondah, 1994; Obonyo, 2003; Ogola, 2011). As some have pointed out,

\footnotetext{
${ }^{6}$ See https://www.kbc.co.ke. [Accessed 18 July 2020].

${ }^{7}$ See https://www.nationmedia.com/brands/. [Accessed 18 July 2020].

${ }^{8}$ See https://www.standardgroup.co.ke/our-brands. [Accessed 18 July 2020].
} 
these laws relied upon pre-independence Statutes, which, for the most part, did not encourage critical media (Mbeke, 2008; Oriare and Mshindi, 2008).

Section 79, "Protection of Freedom of Expression", which guided freedoms of speech and freedom of media until the 2010 constitution read:

Except with his own consent, no person shall be hindered in the enjoyment of his freedom of expression, that is to say, freedom to hold opinions without interference, freedom to receive ideas and information without interference, freedom to communicate ideas without interference (whether the communication be to the public generally or to any person or class of persons) and freedom from interference with his correspondence (Article 79, The Constitution of Kenya, 2001 - revision of 1998 version).

While there is nothing indicative of malice in the above clause, what is interesting to observe is the vagueness and broadness of subsections $79 a, 79 b$ and $79 \mathrm{c}$, which suggested the outlined freedoms could be revoked for the "interests of defence, public safety, public order, public morality or public health" (79a); or for the "purpose of protecting the reputations, rights and freedoms of other persons or private lives of persons concerned in legal proceedings, preventing the disclosure of information received in confidence, maintaining the authority and independence of the courts or regulating the technical administration or the technical operation of telephony, telegraphy, posts, wireless broadcasting or television" (79b). The said freedoms were also threatened if an individual "imposes restrictions upon public officers or upon persons in the service of a local government authority, and except so far as that provision or as the case may be, the thing done under the authority thereof is shown not to be reasonably justifiable in a democratic state" (79c).

Understandably, the broad scope of section 79 provided more wiggle room for successive governments to conveniently interpret what constituted violations of "national security", protection of "reputations, rights and freedoms of others", etc. As some pointed out, section 79 did not explicitly mention media practice thereby providing the state with the powers to limit editorial independence (Mbeke, 2008; Moggi and Tessier, 2001). In particular, it was unclear what defined/constituted media and journalistic practice. In addition to invoking the interests of national security as grounds to contain political dissent, the issuance of broadcast license was limited to a handful of media organizations for easy monitoring by state agencies. This, in part, discouraged media growth in the 1990s and early 2000s (Mbeke, 2008; Oriare and Mshindi, 2008). However, despite the restrictive media environment, investigative journalism was on the rise, keeping the public abreast of issues of public concern such as high-profile corruption by state bureaucrats and corporate elites. The uncovering of the Anglo Leasing Scandal, implicating retired president Moi and several other cabinet ministers within the Kibaki government, is a good example of the early beginnings of investigative journalism in the country (Bachelard, 2010; Okoth, 2016).

As Bachelard (2010) observes, Anglo-Leasing involved a US\$35 million scandal unearthed by John Githongo, then Permanent Secretary of Governance and Ethics, but whose inquiry was blocked by the Kibaki government. Despite the 
state's reluctance to tackle issues of corruption by senior state bureaucrats, public support for investigative journalism and critical media continued. However, it also became common for journalists and whistle-blowers bringing such topics to public's attention to face intimidation, hefty fines, and attacks (Jarso, 2010; Helander, 2010; Oriare and Mshindi, 2008). Although NARC government gave high hopes for reforms following the 2002 elections, media operations were still guided by the broad section 79 of the old constitution, at least until 2010 when Kenyans adopted a new constitution. NARC government used the broad regulatory framework to control media content on issues such as the abuse of power. This was the case in 2006 when the police stormed into The Standard Group buildings at night, seizing broadcast equipment and burning newspaper copies to prevent their circulation the following morning (Ogenga, 2013; Ogola, 2015). This sat at odds with the anticipated reforms and served as a reminder that the media environment under NARC was not any different. In fact, no major media reforms took effect until the early 2008 , following the $2007 / 08$ post-election violence.

Although the state's media capture continues to be a worrying trend, journalistic practices have also eroded over the years due to "the prevalence of corruption in journalism in Kenya" (Ireri, 2016, p. 245) and, to some extent, lack of professionalism in journalistic practices. Obviously, this is not the case for all media organizations. As Mbeke, Ugangu and Okello-Orlale (2010) observe, "large media organisations such as Nation Media Group, Standard Group, Royal Media Services and Radio Africa produce products and services that indicate a high level of professionalism" (p. 28). Given this, it would be false to suggest that the continued strains put on media operation are purely due to the poor levels of journalistic professionalism. Nonetheless, the growing infiltration of political and corporate interests in the determination what is newsworthy is worrisome.

In terms of media regulatory bodies, two "independent" organs guided media practice up until 2013: Communication Commission of Kenya - CCK (now Communication Authority of Kenya) and Media Council of Kenya - MCK (with amendments in 2013). CCK's mandate included, among others, the licensing of telecommunication services, approval of communication equipment, management of radio frequency spectrum, and implementation of universal service obligations for telecom and postal services (Mitullah et al., 2015). Although the Commission identified itself as an independent body, most of its activities were supervised by the former Ministry of Information and Communication. It is therefore not surprising that licencing privately-owned media was selective, with audience reach limited to select urban areas. MCK, on the other hand, was mandated with the task of setting the standards of journalistic practice. On a broader scale, MCK acted as an arbitration body between the media, the public and the government.

With the adoption of the 2010 constitution, the parliament adopted a series of relegations in 2013 which saw changes in the existing media governing bodies. Among them were the Kenya Information and Communication - Amendment Act (KICA) and Media Council Act, which amended the operations of CCK and MCK by establishing the Communication Authority of Kenya (to replace CCK) and Media Council of Kenya (with a revised mandate). These Acts supplement 
Articles 33 (freedom of expression), 34 (freedom of the media), and 35 (access to information) of the 2010 constitution, all of which target media practice. Article 33 provides that freedom of expression does not allow the circulation of content that promotes "propaganda for war; incitement to violence; hate speech; or advocacy of hatred that - constitutes ethnic incitement, vilification or others or incitement to cause harm; or is based on any ground of discrimination"9. Article 34, on the other hand, observes that "the State shall not - (a) exercise control over or interfere with any person engaged in broadcasting, the production or circulation of any publication or the dissemination of information by any medium; or (b) penalise any person for any opinion or view or the content of any broadcast, publication or dissemination"10. Finally, Article 35 states that "(1) every citizen has the right of access to - (a) information held by the State; and (b) information held by another person and required for the exercise or protection of any right or fundamental freedom"11.

Whereas these regulations provide some clarity with respect to contemporary media operations, the arrival of the Jubilee regime in 2013 has brought with it new changes in media and journalistic practices. Because Kenya has been the victim of numerous terrorism attacks in recent years, the Jubilee government has enacted policies around the dissemination of information on terrorist attacks, including public access to and use of government information or records. The Access to Information Law signed by President Uhuru Kenyatta in 2016 is indicative of these changes ${ }^{12}$. Although it is unquestionable that taking measures on news content generating unwarranted public fear is necessary, such measures, if left unchecked, create incentives for repressive media bills/Acts. In fact, recent reports suggest that the adoption of policies limiting media coverage of insecurity has largely contributed to decline in Kenya's Media Freedom Index since $2013^{13}$.

While it is also true that such normative indexes are subject to mixed interpretations, what is certain is that media coverage of the government in a negative light (e.g., covering police brutality) often culminate into tight media regulations and attacks on journalists. For example, media coverage of terrorist attacks at Westgate Mall and Garissa University in 2013 and 2015, which exposed government insufficiencies in matters of domestic security, soured state-media relations at a time when issues of insecurity continue to dominate national politics (Onguny, 2020). The exposure of the lootings perpetrated by the defence forces at Westgate Mall while securing the premises was also deemed "insightful" or "propaganda" by the state despite video evidence (Robertson et al., 2013; Zadock, 2013). These are few of the many examples that show the delicate balance between factual reporting and avoiding what the state deems as incitement. Recent clampdown on journalists who publicize the number of Kenyan deference forces

\footnotetext{
${ }^{9}$ See Constitution of Kenya, Article 33(2) "Freedom of expression" http://www.klrc.go.ke/index.p $\mathrm{hp} /$ constitution-of-kenya/112-chapter-four-the-bill-of-rights/part-2-rights-and-fundamental-freedom s/199-33-freedom-of-expression. [Accessed 20 March 2019].

${ }^{10}$ Ibid, Article 34.

${ }^{11}$ Ibid, Article 35.

${ }^{12}$ The details of this Act can be found here: https://www.cuk.ac.ke/wp-content/uploads/2018/04/Ac cess-to-Information-ActNo31.pdf. [Accessed 20 March 2019].

${ }^{13}$ See Reporters Without Borders https://rsf.org/en/kenya. [Accessed 30 August 2018].
} 
killed in Somalia also highlights the growing use of "unwritten rules" to limit media coverage of security-related issues (Einashe, 2016). National security is often used as an excuse to limit journalists' coverage of inefficiencies in internal insecurity.

The highly contested general elections in 2017 and subsequent nullification of the presidential results also add to the worrying political interference in media. The switching off of the signals of major TV stations (e.g., Nation TV, Kenya Television Network, Citizen TV, and live K24) and their subsidiary radio stations in 2018 highlights this concern (Burke, 2018). Worse, with accusations of bias coverage from both the opposition and the incumbent government, journalists and news editors remain the primary targets of harassment, intimidation, and physical attacks, most of which are perpetrated by the police and military forces (Einashe, 2016; Ogola 2015; Onguny, 2016). Policing online content has also increased in recent years to reduce the circulation of hate messages online (Posetti and Matthews, 2018). Unfortunately, independent news bloggers covering the state in a negative light have been the primary targets of police brutality ${ }^{14}$. In a sense, these dynamics force journalists and news editors into cooperating with the state in exchange for "freedom".

Overall, these examples not only show the dilemmatic state-media relations; they also highlight the recursive influence between media environments and journalistic practices. This, of course, is not anything new. A number of studies, including those specific to Kenya, have shown how media environments influence the journalistic field. Lohner et al. (2016), for instance, emphasize conditions such as "...(1) historical development, (2) political system, (3) political culture, (4) media freedom, (5) level of state control and regulation of media by the state, (6) media ownership and financing, (7) structure of media markets and patterns of information distribution, (8) orientation of media, (9) political/societal activity and parallelism of media, (10) journalism culture, and (11) journalistic professionalism" (p. 1). Other studies have coined these conditions more broadly as "media fields" (Benson, 2006; Couldry et al., 2010), which invites critical reflections on the complex and multilayered relationship between media forms and content. To put it in Benson's (2006) words, "it is just as much a mistake to locate journalistic (or any other form of specific cultural) autonomy on the side of a paternalistic as on the side of a privatizing state" (p. 197). This is because media quality also depends on the degree to which it is aligned with commercial interests, political parties, and ethnic group interests. Admittedly, journalistic culture, including the problems of bribery and corruption, must be examined closely if issues of impunity are to be dealt with in a meaningful manner.

\footnotetext{
${ }^{14}$ See reports by the Freedom House https://freedomhouse.org/report/freedom-press/2016/kenya. [Accessed 21 August 2018].
} 


\section{Political Impunity, "Policy Laundering", and "Critical Junctures"}

As argued in the previous sections, the shifts in media regulatory frameworks have largely been influenced by the changes in political environment. Over the years, the media sector has been the target of varying repressive bills, often justified on the grounds of national security and curbing irresponsible journalism. Although this is sometimes true, given the infiltration of corruption at the editorial levels (see Ireri, 2016; Kanyinga, 2014), the temporal survey of media regulations presented shows how the changes in political environments influence media regulations/policies across regimes. It is no surprise that there is a correlation between regime change and fluidity in media regulatory mechanisms.

Several studies specific to Kenya have documented the attempts by the state to implement controversial media bills often with little to no consultation with media owners' associations or the union of journalists (Oriare and Mshindi, 2008; Mitullah et al., 2015; Obonyo and Peel, 2012). For years, this was commonplace, as many media policies followed similar paths in the implementation process. If some of the proposed regulations/policies failed to materialize, it is probably due to the uproar by public and media activists. Examples of such attempts include the failed effort to establish a Task Force of Press in 1993 by the KANU government (Mbeke, 2008). This was followed by another attempt, in 1995, to introduce the Kenya Mass Media Commission Bill and Press Council of Kenya Bill, both of which failed due to pressure exerted on the government by media and human rights activists (Moggi and Tessier, 2001).

In an attempt to make sense of the shifts in media regulatory environment, some have argued that the creation of the Kenya Union of Journalists (KUJ) in 1998 and subsequent formation of the Media Council of Kenya (MCK) in 2002 (with operations in 2004) were largely due to the concerns that the state was increasingly seeking ways to stifle independent media operations (Mbeke, 2008). This is probably why the then MCK established the Code of Conduct and Practice of Journalism in Kenya to guide journalists through their news coverage. Despite these measures, the existence of independent media regulatory bodies has never stopped state-led attacks on journalists and their respective media organizations. The invasion of the Standard Media Group by state officials in 2006 and 2008 serves as an example (Onguny, 2016). The failed 2007 policy that required journalists to disclose their sources to the police forces and/or courts is another clear example of the state's attempts to establish policies limiting the exposure of acts of impunity (Ogola, 2015). For some, these challenges raise the question of whether the media should self-regulate, or the state should take active role in regulating the media (Obonyo and Peel, 2012). This, according to Obonyo and Peel (2012), remains the fundamental question that needs "to be negotiated between the media, those in power and the general public" (p. 139). Static constitutional amendments up until the 2010 constitution also highlight the commitment by successive governments to restrict reforms for political reasons.

Despite the changes in regime, the media environment has remained volatile. Under the first regime (1963-1978), Jomo Kenyatta made a handful of changes to the constitution to reflect Kenya's newly gained sovereignty (Faringer, 1991; 
Dixon, 1997; Okoth-Owiro, 1990). Meanwhile, under Daniel Moi (1978-2002), wide-ranging media policies were enacted with little public consultation (Helander, 2010; Ogola, 2011). During Kibaki's NARC government (20022013), media operations were still closely monitored by the state even though there was an exponential growth of commercial and independently-owned news media during this period (Ogola, 2015). Under Uhuru Kenyatta's Jubilee government (2013 to date), regulatory bodies have seen their powers amended (the 2013 Information and Communication Act) and a Tribunal (Multimedia Appeals Tribunal) established to address complaints against journalists and media houses (Media Policy Research Center, 2015). One emerging concern is that the Tribunal in question is not entirely independent of the state, raising serious questions with regard to fair hearing of journalists. For instance, a successful compliant may cost media houses up to USD \$20000 in fines, while individual journalists risk fines up to USD $\$ 5000^{15}$. Certainly, the hefty fines have become important deterrent mechanisms aimed at co-opting journalists and news editors into friendly coverage of the state and its operations (Zadock, 2013).

This does not mean journalistic practices, particularly the smaller news outlets, do not leave much to be desired in terms of professionalism and or ethnical conduct. Several studies on the relationship between the Kenyan media and state have highlighted the central role played by news editors and journalists in institutionalizing corruption and impunity by accepting bribes or "brown envelops" to "kill" certain stories (see Helander, 2010; Ireri, 2016; Kanyinga, 2014). While acknowledging the complex media-state relations, the argument advanced here is that successive regimes use regulations as a proxy to conveniently define what journalism is or should be. In turn, this impacts the manner in which the media covers issues of political impunity.

This fluidity in media regulations could be understood as a form of policy laundering, defined by Hosein $(2006,228)$ as "a practice where policy makers make use of other jurisdictions to further their goals, and in so doing circumvent national deliberative processes". According to Hosein (2006), two factors are indicative of a policy laundering environment. First, the "national consultative processes disappear or are weakened, as important policy decisions take place outside our traditional democratic institutions" (p. 228). Second, "policies are shaped by foreign interests and foreign processes" (p. 228). The notion of policy laundering captures the complex environment within which media regulations are established in Kenya. Whereas it is unquestionable that the challenges of national security have been on the rise (Onguny, 2020), it is increasingly becoming risky for journalists to expose scandals in government without political interference on news content, even though recent efforts against corruption are applauded. The coverage of opposition events during election cycles and police brutality have also been conveniently construed by the state as dissemination of "inciteful" information likely to cause public fear (Burke, 2018; Human Rights Watch, 2018).

\footnotetext{
${ }^{15}$ See reports by the Freedom House https://freedomhouse.org/report/freedom-press/2016/kenya. [Accessed 21 August 2018].
} 
As a result, some news anchors have resigned from mainstream media outlets due to arbitrary interference with news content ${ }^{16}$.

Overall, these cases show the linkages between regime change and the shifts in state-media relations. The longstanding question remains whether the Kenyan media is at a crossroads. To borrow from McChesney (2007), the answer lies in how "critical junctures" are used to bring about the desired change in an unravelling political environment. In writing about communication revolution, McChesney (2007) argued that media systems should take advantage of the "rare window of opportunity" provided by communication transformations (supported by digital revolution) to effect democratic media reforms. This is because such transformations provide "an unprecedented (rare window of opportunity in the next decade or two) to create a communication system that will be a powerful impetus (for) a more egalitarian, humane, sustainable, and creative (selfgoverning) society" (McChesney, 2007, p. ii and iii). It is the rarity in such opportunities that McChesney (2007) sees as "critical junctures" that should be seized upon in order to democratize media environments. According to him, media systems have become oligopolies that represent special interests rather than public interests. This is also because of the diminishing "corporate stranglehold over media system", increasingly challenged by citizens. Arguably, the biggest huddle for media systems remains the preservation of internet neutrality from government and corporate interference in the flow and/or circulation of information.

Although McChesney's work draws primarily on the American media system, its history, and political-economic realities, its relevance in understanding the challenges facing media systems stretches beyond the American context. Accordingly, "critical junctures" are crucial moments likely to bring about changes within a shifting media structure that, otherwise, would never be possible. Given the growth and expansion of mobile telephony and digital media spaces in Kenya (Onguny, 2014), local media systems hold the potential to effect changes that would see an increased public participation in the key debates affecting the country. This, of course, would only be possible if media actors (e.g., media owners, journalists, sponsors, activists, etc.) take active part in the ongoing discussions about referendum and possible constitutional change alongside the newly proposed Building Bridges Initiative (BBI).

\section{Conclusion}

This article discussed the interconnections between media regulations, statemedia relations, and the shifts in Kenya's media landscape. It argued that broad media regulations provide room to nurture an environment of self-censorship, particularly on matters of corruption and political impunity. The article adopted a political economic approach to assess the key temporal periods and how they have variably contributed to media regulatory framework, including media reach and concentration. It argued that these shifts influence journalistic practices, editorial

\footnotetext{
${ }^{16}$ Ibid.
} 
independence, and the overall media landscape in Kenya. These discussions are located in contexts of "policy laundering" to highlight the rapidly changing media and political environments.

Obviously, the regulations discussed here are not, by any means, exhaustive given the rapidly changing media landscape in Kenya. In fact, the ongoing discussions about the BBI and the looming referendum aimed at amending the current Constitution ahead of the 2022 elections are a clear indication of the continually shifting media environment. If seized as a "critical juncture", media organizations or unions could take an active role in negotiating media reforms in areas such as the protection and safety of journalists. Other reforms could target transparency and accountability of state bureaucrats such as pushing for live broadcast of parliamentary proceedings. Bringing clarity to broad clauses could also limit convenient interpretations that criminalize online political dissent or abusive attacks on independent political bloggers. This is because opinion pieces are part of a vibrant media environment contributing to the diversity of media content. Since the majority of media outlets are owned by politicians or influential businesspersons, revisiting media ownership patterns may be something worth pursuing.

Finally, and because journalists and news editors also play a central role in facilitating and/or institutionalizing political impunity, media owners can consider ways of incentivizing journalists/editors who uphold the highest journalistic ethics. Evidently, these are ambitious reforms whose degree of plausibility will highly depend on the political environment in place. Overall, if the patterns of media regulations described here are anything to go by, the new regime anticipated in 2022 is likely to bring with it new changes to media regulatory frameworks.

\section{References}

Bachelard, J. Y. (2010). The Anglo-leasing corruption scandal in Kenya: the politics of international and domestic pressures and counter-pressures. Review of African Political Economy, 37(124), 187-200.

BBC Media Action (2017). Strengthening accountability through media in Kenya. Retrieved from: http://dataportal.bbcmediaaction.org/site/assets/uploads/2017/07 /Kenya-Country-Report-2017.pdf. [Accessed 27 August 2018].

Benson, R. (2006). News media as a "journalistic field": what Bourdieu adds to new institutionalism, and vice versa. Political Communication, 23(2), 187-202.

Burke, J. (2018). Kenya's opposition swears in Raila Odinga as "people's president". The Guardian. Retrieved from: https://www.theguardian.com/world/2018/jan/30/kenyasopposition-to-swear-in-raila-odinga-as-peoples-president. [Accessed 28 August 2018].

Couldry, N., Livingstone, S., Markham, T. (2010). Media consumption and public engagement: beyond the presumption of attention. New York: Palgrave Macmillan.

Dixon, D. N. (1997). Press law debate in Kenya: ethics as political power. Journal of Mass Media Ethics, 12(3), 171-182.

Einashe, I. (2016). Kenya clamps down on journalists covering war on Al-Shabaab. The Guardian. Retrieved from: https://www.theguardian.com/world/2016/jun/27/kenya- 
clamps-down-on-journalists-covering-war-on-al-shabaab. [Accessed 28 August 2018].

Faringer, G. L. (1991). Press freedom in Africa. New York: Praeger.

Fuchs, C. (2010). Alternative media as critical media. European Journal of Social Theory, 13(2), 173-192.

Haugerud, A. (1995). The culture of politics in modern Kenya. Cambridge: Cambridge University Press.

Hosein, G. (2006). Policy laundering and other policy dynamics. In E. Haplpin (Ed.) Cyberwar, netwar and the revolution in military affairs (pp. 228-253). London: Palgrave Macmillan.

Helander, E. (2010). A critical view of the Kenyan media system through the perspective of the journalists. African Communication Research, 3(3), 521-542.

Hudson, D., Marquette, M. (n.d.). Mind the gaps: what's missing in political economy analysis and why it matters. Retrieved from: https://www.oecd.org/dac/accountableeffective-institutions/Governa nce\%20Notebook\%201.3\%20Hudson\%20et\%20al.pdf . [Accessed 12 May 2019].

Humans Rights Watch (2018). Kenya: Media barred from opposition event. Retrieved from: https://www.hrw.org/news/2018/01/30/kenya-media-barred-oppositionevent. [Accessed 28 August 2018].

Ireri, K. (2016). Do they preach water but drink wine? Examining "the corruption dragon" in Kenyan journalism. Journal of Media Ethics, 31(4), 245-59.

ITU (2017). Digital migration process in Kenya. Retrieved from: https://bit.ly/3fPzC Vv. [Accessed 28 August 2018].

Jarso, J. (2010). The media and the anti-corruption crusade in Kenya: weighing the achievements, challenges, and prospects. American University International Law Review, 26(1), 32-88.

Kanyinga, K. (2014). Democracy and political participation. Nairobi: Open Society Initiative for Eastern Africa.

Lohner, J., Banjac, S., Neverla, I. (2016). Mapping structural conditions of journalism in Kenya. Media Conflict and Democratization. Retrieved from: https://bit.ly/2W swHKy. [Accessed 21 August 2018].

Lynch, G. (2008). Courting the Kalenjin: The Failure of Dynasticism and the Strength of the ODM Wave in Kenya's Rift Valley Province. African Affairs, 107(429), 541568.

Lynch, G. (2014). Electing the "alliance of the accused": the success of the Jubilee Alliance in Kenya's Rift Valley. Journal of Eastern African Studies, 8(1), 93-114.

Mbeke, P. O. (2008). The media, legal, regulatory and policy environment in Kenya. Policy Briefing No. 1. BBC World Service Trust.

Mbeke, P. O., Ugangu, W., Okello-Orlale, R. (2010). The media we want. The Kenya media vulnerabilities study. Friedrich Ebert Stiftung (FES). Retrieved from: https://library.fes.de/pdf-files/bueros/kenia/07887.pdf. [Accessed 10 January 2019].

McChesney, R. (2007). Communication revolution: critical junctures and the future of media. New York: The New Press.

Media Policy Research Center (2015). State of the media in Kenya 2014: uncertainty, resistance and change. Nairobi: Media Policy Research Center.

Mitullah, W. V., Mudhai O. F., Mwangi, S. (2015). Background paper: politics and interactive media in Kenya. Politics and Interactive Media in Africa. Retrieved from: https://core.ac.uk/reader/77408486. [Accessed 10 January 2019].

Moggi, P., Tessier, R. (2001). Media status report: Kenya. Nairobi: Groupe de Recherche et d'Échanges Technologiques (GRET). 
Mueller, S. D. (2014). Kenya and the International Criminal Court (ICC). Politics, the election and the law. Journal of Eastern African Studies, 8(1), 25-42.

Muhatia, A. (2017). Government to seek lower ad rates from media houses. The Star. Retrieved from: https://www.the-star.co.ke/news/2017/09/06/governm ent-toseek-lower-ad-rates-from-media-houses_c1630127. [Accessed 28 August 2018].

Obonyo, L. (2003). The background of Kenya press. In A. Quick (Ed.) World press encyclopedia: a survey of press systems worldwide (pp. 529-539). New York: Gale Group.

Obonyo, L., Peel, C. (2012). Media regulation in emerging democracies: The example of Kenya's hybrid model. African Communication Research, 5(2), 139-159.

Ochilo, J. P. (1993). Press freedom and the role of the media in Kenya. Africa Media Review, 7(3), 19-33.

Ogenga, F. (2013). The media coverage of the Hague trials and the construction of new ethnic subjectivities in Kenya. African Conflict \& Peacebuilding Review, 3(1), 158174.

Ogbondah, C. (1994). Press freedom and political development in Africa. Africa Media Review, 8(3), 20-31.

Ogola, G. (2011). The political economy of the media in Kenya: from Kenyatta's nation-building press to Kibaki's local-language FM radio. Africa Today, 57(3), $77-95$.

Ogola, G. (2015). African journalism: a journey of failures and triumphs. African Journalism Studies, 36(1), 93-102.

Okoth, A. (2016). Increasing the oversite role in the usage of public funds in Kenya. Maryland: John Hopkins University.

Okoth-Owiro, A. (1990). Law and mass media in Kenya. Africa Media Review, 4(1), 14 26.

Onguny, P. (2014). Potential of mobile media as a space for political deliberation in subSaharan Africa. Rhodes Journalism Review, 34(0), 71-74.

Onguny, P. (2016). Indigenous language radios in Kenya and the negotiation of intergroup relations during conflict processes. In A. Salawu, M. Chibita (Eds.) Indigenous language media, language politics and democracy in Africa (pp. 151-181). London: Palgrave Macmillan.

Onguny, P. (2020). Framing the war on terror in Kenya: perspectives on the attacks at Westgate Mall and Garissa University. African Journal of Terrorism \& Insurgency Research, 1(1), 77-101.

Oriare P. M., Mshindi, T. (2008). Kenya media sector analysis report. Nairobi: Canadian International Development Agency (CIDA).

Posetti, J., Matthews, A. (2018). A short guide to the history of fake news and disinformation: a new ICFJ learning module. International Center for Journalists. Retrieved from: https://bit.ly/3fCCO6D. [Accessed 10 January 2019].

Robertson, N., Verjee, Z., Smith-Spark, L. (2013). Kenya mall attack video fuels army looting claims. CNN. Retrieved from: https://www.cnn.com/2013/10/22/world/ africa/kenya-mall-attack-looting/index.html [Accessed 28 August 2018].

Schifrin, A. (2017). In the service of power: media capture and the threat to democracy. Washington: Center for International Media Assistance (CIMA).

Schmidt, C., Deselaers, J. (2015). Kenya's media landscape - everyday constraints and structural challenges. In C. Schmidt (Ed.) Kenya's media landscape: a success story with serious structural challenges (pp. 10-26). Leipzig: VISTAS Verlag.

Shilaho, W. (2013). Old Wine in New Skins: Kenya's 2013 elections and the triumph of the ancien régime. Journal of African Elections, 12(3), 89-119. 
Shilaho, W. K. (2018). The International Criminal Court (ICC), impunity, and the elusive justice in Kenya. In political power and tribalism in Kenya (pp. 143-163). Cham: Palgrave Macmillan.

Somerville, K. (2012). Kenya: political violence, the media and the role of vernacular radio stations. In Radio propaganda and the broadcasting of hatred (pp. 208-237). London: Palgrave Macmillan.

Wasserman, H. (2020). Fake news from Africa: panics, politics and paradigms. Journalism, 21(1), 3-16.

Widner, J. A. (1992). The rise of a party-state in Kenya: from "Harambee!" to "Nyayo!". Berkeley: University of California.

Zadock, A. (2013). Westgate: Kimaiyo now threatens journalists. Daily Nation. Retrieved from: https://www.nation.co.ke/news/Reporters-face-arrest-for-exposing-Westgatelooting/1056-2044972-fq7ogxz/index.html. [Accessed 28 August 2018]. 